\title{
AC 2009-1920: ABET ACCREDITATION: RESOLVING A WEAKNESS OR CONCERN
}

\section{John Irwin, Michigan Technological University}

Dr. John Irwin has presented published papers at the ASEE conferences in 2002, 2006, 2007 and 2008 in the Engineering Technology and Engineering Graphics Divisions. Dr. Irwin in 2006 joined the School of Technology at Michigan Technological University as Associate Professor, MET and is also Chair of the MET and Industrial Technology programs. He has a Master's degree in Occupational Education from Ferris State University, Big Rapids, Michigan and a Doctorate in Curriculum and Instruction from Wayne State University, Detroit, Michigan. Dr. Irwin has also been a Program Manager for a NSF grant awarded in the ATE program area from 2002-2006. He is experienced in industry as well as the teaching profession with a career spanning five years in engineering design, several years part time consulting in industry and 21 total years of teaching first high school, then community college and presently university level courses in the engineering technology subject area. Dr. Irwin has a research focus on evaluation of teaching and learning in the area of computer aided design, analysis, \& manufacturing subjects introduced in the STEM related courses in K-16 educational levels.

\section{Nasser Alaraje, Michigan Technological University}




\title{
ABET Accreditation - Resolving a Weakness or Concern
}

\begin{abstract}
The Accreditation Board for Engineering and Technology (ABET) criterion for Assessment and Evaluation are discussed from the perspective of a Mechanical Engineering Technology (MET) program's experience with the ABET Technology Accreditation Committee (TAC) re-accreditation process. Specifically, the resolving of the institutional weakness related to the MET program in the 2007-08 Criterion 3: Assessment and Evaluation, (2008-09 ABET-TAC Criterion 4: Continuous Improvement). The resolution of the weakness discussed is related to the clear distinction between program educational objectives and program outcomes, the relationship of the ABET-TAC Criterion 2 [a-k] to each objective, and the assessment measures and metrics associated with each objective. An assessment methodology implemented to resolve this weakness is described along with examples of data measurement tools utilized. Advantages and disadvantages of data collection methods are analyzed in this report, given that there is not one single method of measurement that can predict program improvement. A distinction is made between the program educational objectives assessment tools: job placement data; alumni survey; employer survey; and input from industrial advisory board, and the program outcome assessment tools: course assessment; student rating of instruction; senior exit exam; senior project evaluation; and senior exit survey. Each assessment tool is discussed in relation to the criteria (or metric used), results, and use of the results for continuous improvement. Techniques to assist in gathering the data, such as the use of online survey tools are presented to lessen the burden on the assessment team, as well as plans for the future.
\end{abstract}

\section{Introduction}

The MET and EET programs were evaluated during a site visit in October, 2005 while seeking reaccreditation of their respective programs by ABET-TAC. The ABET response after the 2006 Summer Meeting was to accredit the programs to September 30, 2008, and require that a request be made to ABET by January 31, 2007 for a reaccreditation report evaluation. Also, a report describing the actions taken to correct the shortcomings identified needed to be submitted to ABET by July 1, 2007. One of the Institutional Weaknesses reported by ABET was Criterion 3: Assessment and Evaluation stating that each program had ambitious plans, but neither program had collected data from every assessment measure. Also, there were no documented examples to show that the continuous loop had been closed by way of program improvement.

The response to this assessment was that the MET program, realizing the plan was too ambitious for the available resources, decided to benchmark other institutions and then revisit the program goals and objectives re-linking them to the a-k criteria to be completed by April 28, 2006. As requested, on July 28, 2007 a Reaccreditation Report was submitted to ABET outlining the corrective actions taken for the identified shortcomings. Included in this report was an updated MET Assessment Plan, including (3) attachments: The Assessment Process Overview; The Updated List of Program 
Educational Objectives with linked a-k criteria and measures; and a Summary of MET Program Improvements. These documents illustrated a simpler process that was developed and implemented in 2006-07, and how this process closed the loop for continuous improvement.

On November 27, 2007 a Draft Statement by ABET-TAC was that the Criterion 3 Assessment \& Evaluation, finding will remain a Weakness until the MET program (a) demonstrates a clear distinction between its program objectives and program outcomes, (b) demonstrates the relationship of Criterion $2[\mathrm{a}]-[\mathrm{k}]$ to each objective, and (c) demonstrates the assessment measure and metrics associated with each objective. On January 3, 2008 it was communicated to ABET that a response to this finding would be provided at a later date.

Finally, in response to the findings, the MET Program Spring 2008 Assessment Report was submitted to ABET prior to the 2008 Summer Meeting. This report included a revised version of the previously submitted attachments, along with assessment results and analysis in a tabular format. Following the 2008 Summer Meeting the final response on August 15, 2008 from ABET was that the MET Program be reaccredited.

I believe that it is also pertinent to this discussion that within this time period from 2004 - 2008 three different MET Department Coordinators (Chairs) traded off the responsibilities of developing and coordinating the assessment and evaluation plan. The first person holding the Chair position developed the original Self Study Report prior to the site visit, the second Chair was responsible for the Reaccreditation Report, and the third Chair position developed the final Spring 2008 Assessment Report. It is also relevant to understand that each response and report was a team effort in collecting information, developing methods of assessment and evaluation, and analyzing the information, but the pulling of the material together to be presented to ABET was the responsibility of the Chair at that particular time.

The following information will be an account of modifications and improvements that were made in the reaccreditation process to move from the Weakness finding to a resolution. Also, some insight into what strategies were used by the faculty involved in assessment and evaluation activities throughout the process.

\section{Background}

At this University, the School of Technology (SoT) is home to six Bachelor of Science Degree Programs; Computer Network and System Administration, Construction Management, , Industrial Technology, Surveying Engineering, EET, and MET. Of the programs listed, the EET and MET are the only ABET-accredited degrees, and currently the MET program enrollment is approximately 100 students. The SoT started offering Baccalaureate degrees in 1994 and discontinued offering Associate's Degrees. With the elimination of the Associate degree option, the MET curriculum was redesigned based on extensive benchmarking of comparable university degree offerings, industry needs, and 
advisory input. Table 1 provides a summary of the core courses, prerequisites/restrictions, when offered, and the number of credits.

Table 1 - Core Courses in the MET Curriculum 2008-09

\begin{tabular}{|c|c|c|c|c|c|c|}
\hline \multicolumn{5}{|c|}{ Mechanical Engineering Technology Major - Required } & \multicolumn{2}{|c|}{ Total: 60} \\
\hline Course & Title & Prerequisites/Restrictions & Offered & Taken & Grade & Credits \\
\hline $\begin{array}{l}\text { BA } 2330 \\
\text { OR }\end{array}$ & $\begin{array}{l}\text { Accounting I } \\
\text { OR }\end{array}$ & SO,JR,SR & $\mathrm{f} / \mathrm{s} / \mathrm{su}$ & & & $\mathrm{OR}^{3(3-0-0)}$ \\
\hline BA 3610 & Operations Management & BA 2100 or MA 2710 or 3710 & $\mathrm{f} / \mathrm{s} / \mathrm{su}$ & & & $3(3-0-0)$ \\
\hline EC 3400 & Economic Decision Analysis & UN 2002 / JR,SR / non-SBE & $\mathrm{f} / \mathrm{s} / \mathrm{su}$ & & & $3(3-0-0)$ \\
\hline EET 1411 & Basic Electronics & MA1030(C) & s/su & & & $4(0-3-2)$ \\
\hline EET 3131 & Instrumentation & EET 1411 or 2311 or 2220 & $\mathrm{~s}$ & & & $3(0-2-2)$ \\
\hline EET 3700 & $\begin{array}{l}\text { Electrical Power, Machinery \& PLC } \\
\text { Basics }\end{array}$ & $\begin{array}{l}\text { EET } 1411 \text { or } 2311 \text { or } 2220 \text { or } \\
\text { EE } 3010 / \text { non-TEE.TEET.TEM }\end{array}$ & s & & & $4(0-3-3)$ \\
\hline $\begin{array}{l}\text { MEEM } \\
2500\end{array}$ & Integrated Design \& Manufacturing & $\begin{array}{l}\text { ENG } 1102 \text { \& MY } 2100(\mathrm{C}) / \\
\text { non-ENG,EME,EBE }\end{array}$ & $f / s$ & & & $4(0-3-3)$ \\
\hline MET 1540 & Materials Science & $\mathrm{CH} 1000$ or $\mathrm{CH} 1100$ & $\mathrm{~s}$ & & & $3(0-3-0)$ \\
\hline MET 2120 & Statics \& Strength of Materials & $\begin{array}{l}\text { MA } 1140(\mathrm{C}) \text { or MA } 1160(\mathrm{C}) \text { or } \\
\text { MA } 1161(\mathrm{C}) \& \mathrm{PH} 1140\end{array}$ & f & & & $4(0-3-2)$ \\
\hline MET 2130 & Dynamics & MET 2120 & $\mathrm{~s}$ & & & $3(0-3-0)$ \\
\hline MET 2400 & Practical App in Parametric Modeling & TE 1010 & s/su & & & $3(0-2-2)$ \\
\hline MET 3242 & Machine Design I & $\begin{array}{l}\text { MAT } 2215 \text { or MA } 2140 \text { or } \\
\text { MA } 2160 \& \text { MET } 2130\end{array}$ & $f$ & & & $3(0-3-0)$ \\
\hline MET 3250 & Applied Fluid Mechanics & MET 2130 & $f$ & & & $4(0-3-2)$ \\
\hline MET 3450 & Machine Design II & MET 3242 & s & & & $4(0-4-0)$ \\
\hline MET 3600 & Applied Thermodynamics & MET 3250 / JR,SR & s & & & $3(0-2-2)$ \\
\hline MET 4200 & Design of Experiments & MA 2720 or BA 2100 & f/su & & & $3(3-0-0)$ \\
\hline MET 4460 & Product Design and Development & MET 3450 / JR,SR & $\mathrm{f} / \mathrm{s}$ & & & $3(0-2-2)$ \\
\hline MET 4670 & Senior Project & MET 4460 / Instructor Approval / SR & $\mathrm{f} / \mathrm{s} / \mathrm{su}$ & & & $3(0-0-6)$ \\
\hline MET 4999 & Senior Project Seminar $-\mathrm{P} / \mathrm{F}$ & SR & $f / s$ & & & $1(0-1-0)$ \\
\hline TE 1010 & Technology Computer Applications & & f/su & & & $2(0-2-0)$ \\
\hline
\end{tabular}

The present MET degree has three focus areas that students can choose electives during their junior and senior year which are: Manufacturing, Computer Aided Engineering (CAE), or Fluids and Power Systems. As a capstone experience senior year MET students from each of the focus areas are required to complete a team-based senior design project. Students progress through a two semester sequence starting with Product Design and Development presenting integrated methodologies that examine marketing, manufacturing, and cross-functional teams including concurrent engineering and projects utilizing CAD systems, and ending with a Senior Project course including evaluation and design optimization methods for efficient and cost-effective designs requiring an oral/written report. In the capstone sequence the student teams generate the design, optimize the design and document the design. Then, during the last semester the teams plan for production, manufacture and assemble components, and test their design using the skills acquired through the computer-aided engineering and manufacturing related courses taken in earlier semesters.

\section{4-05 Self Study Report - Assessment}

In this original report there were (4) program educational objectives (PEOs), and the ABET a-k criteria were identified as the program outcomes (POs). The Alignment of the PEOs with the POs was explained in a single descriptive paragraph. The alignment of the PEOs and POs to the mission and vision of the SoT and the University was illustrated in a figure. The alignment of the curriculum to the POs was presented using the Outcomes 
Mapping Matrix shown in Table 2. The matrix illustrates in each course which of the a-k are introduced and also to what degree on a scale of 1-3, which relate to; some, moderate, and significant coverage. This method of aligning the POs to the curriculum is a method that has remained in use for the present assessment plan.

\section{Table 2 - Competency Mapping}

\begin{tabular}{|c|c|c|c|c|c|c|c|c|c|c|c|c|c|c|c|c|}
\hline & & & 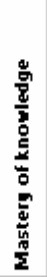 & 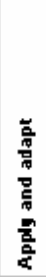 & 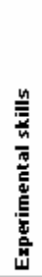 & 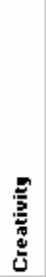 & 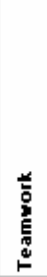 & 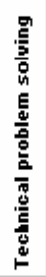 & 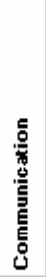 & 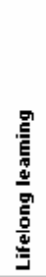 & 䓵 & 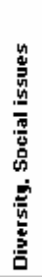 & 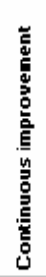 & 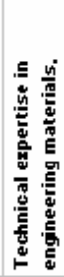 & 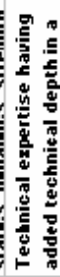 & 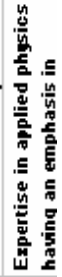 \\
\hline & Course & Description & 2a & $2 \mathbf{b}$ & $2 c$ & $2 \mathbf{d}$ & $2 \mathrm{e}$ & $2 f$ & $2 g$ & $2 \mathbf{h}$ & $2 \mathbf{i}$ & 2j & $2 \mathbf{k}$ & $8 \mathbf{a}$ & $\mathbf{8 b}$ & $8 \mathrm{c}$ \\
\hline & MET3242 & Machine Design I & 3 & & 2 & & 2 & 3 & 3 & & & & 3 & 3 & & \\
\hline & MET 3250 & Applied Fluid Mechanics & 3 & & 2 & & 2 & 3 & 3 & & & & 3 & & & \\
\hline & MET 3450 & Machine Design II & & & & 3 & 3 & 3 & 3 & 1 & 1 & & & & & \\
\hline & MET 3600 & Applied Thermodynamics & 3 & 3 & & & & 3 & & & & & & & & \\
\hline & MET 4200 & Design of Experiments & 3 & 3 & 2 & 1 & 2 & 2 & 1 & & & & 1 & & 3 & \\
\hline & MET 4300 & Applied Heat Transfer & & & & & & & & & & & & & & \\
\hline & MET 4460 & Product Design $t$ Development & 2 & 1 & 2 & 3 & 3 & 3 & 3 & 1 & 2 & 2 & 1 & & 1 & \\
\hline & MET 4670 & Senior Project & & & & 3 & 3 & 3 & 3 & 1 & & & & & & \\
\hline & MET4999 & Senior Project Seminar & 3 & 2 & 2 & & & 3 & & 3 & 1 & & 1 & 1 & 3 & 1 \\
\hline & EET1411 & Basic Electronics & 3 & 2 & 2 & & 1 & 3 & & & & & & & & 2 \\
\hline & EET3131 & Instrumentation & 3 & 2 & 2 & & 1 & 3 & & & & & & & & 2 \\
\hline & EET 3700 & Electrical Pover $t$ PLC Basics & 3 & & 3 & & 1 & 3 & & & & & & 2 & 1 & \\
\hline & & & & & & & & & & & & & & & & \\
\hline Reouired & CH1100 & General Chemistr: & 2 & & 3 & & & 2 & & & & & & & & \\
\hline Math & MA1032 & Data, Functions, *t Graphs & & 3 & & & & 3 & & & & & & & & \\
\hline Physics \& & MA1160/61 & Calculus with Technology I & & 3 & & & & 3 & & & & & & & & \\
\hline Comp. Appl & MA2160 & Calculus vith Technology II & & 3 & & & & 3 & & & & & & & & \\
\hline & PH1140/41 & Applied College Physics I \& Lab & 3 & & 2 & & & 3 & & & & & & & 3 & \\
\hline & PH1240/1200 & Applied College Physics II \& Lab & 3 & & 2 & & & 3 & & & & & & & 3 & \\
\hline & MA2720 & Statistical Methods & 3 & 3 & & & & 3 & & & & & & & & \\
\hline & & & & & & & & & & & & & & & & \\
\hline \multicolumn{17}{|l|}{ Elective } \\
\hline \multirow[t]{13}{*}{ Courses } & MET 4550 & Computer Aided Manufacturing & 3 & 2 & 2 & 3 & 3 & 1 & 2 & & & 1 & 3 & 2 & 3 & \\
\hline & MET 4377 & Applied Fluid Power & 3 & 2 & 3 & 2 & 2 & 3 & 3 & & 1 & 1 & 3 & 3 & 3 & \\
\hline & MET4390 & Internal Combustion Engines & 3 & 2 & 3 & 2 & 2 & 3 & 3 & & 1 & 1 & 3 & 3 & 3 & \\
\hline & MET 4400 & Simulation Methods & 3 & 2 & 1 & & & 3 & & & & & & 1 & 3 & \\
\hline & MET 4450 & Advanced Manufacturing Process & 3 & 2 & 1 & 1 & & 1 & & & & & 3 & & 3 & \\
\hline & MET 4500 & Lean Manuf acturing. Principles. Concepts ar & 3 & 2 & 1 & 2 & 2 & 2 & 2 & 2 & 1 & 1 & 1 & & 3 & \\
\hline & MET4580 & Facilities Planning. Layout t Process Floy & 3 & & 2 & 2 & 3 & 1 & 3 & & & & 3 & & 2 & \\
\hline & MET4590 & Production Planning \& Control & 3 & & 2 & 2 & 3 & 1 & 3 & & & & 3 & & 2 & \\
\hline & MET 4660 & Applied finite Element Analysis & 3 & 1 & 2 & 2 & 2 & 3 & 2 & 1 & 2 & & 3 & 2 & 2 & 1 \\
\hline & TE3956 & Industrial Safety Management & 3 & & & 2 & 2 & 3 & 1 & 2 & 3 & 1 & 2 & 1 & 1 & \\
\hline & UII3002 & Co-op Education Laboratory & & & & & & & 2 & 2 & 2 & 2 & & & & \\
\hline & & & & & & & & & & & & & & & & \\
\hline & Gen Ed (28cr) & & & & & & & & 2 & & 2 & 2 & & & & \\
\hline
\end{tabular}

The method of using Course Binders was discussed in the Self Study Report, where each course has a binder consisting of a 10 tab system maintained by the instructor of record for that particular course. In Table 3 the contents assigned to each tab are explained.

Table 3 - Course Binder Process

\begin{tabular}{|l|l|l|}
\hline Tab & Label & Explanation \\
\hline $\mathbf{1}$ & $\begin{array}{l}\text { Program } \\
\text { Outcomes } \\
\text { Associated with } \\
\text { this Course }\end{array}$ & $\begin{array}{l}\text { The mapping between curriculum and program outcomes } \\
\text { (Criterion 2, a-k) illustrated in Table 2 of this report is } \\
\text { repeated here, but restricted to just the course at hand. A } \\
\text { brief narrative explains how the course supports outcomes. }\end{array}$ \\
\hline
\end{tabular}




\begin{tabular}{|c|c|c|}
\hline 2 & Syllabus & $\begin{array}{l}\text { The most current syllabus for the course is kept on file here. } \\
\text { Course objectives are contained in the syllabus. The course } \\
\text { objectives are written such that achievement of the course } \\
\text { objectives contributes to achievement of the associated } \\
\text { program outcomes (Criterion } 2, \mathrm{a}-\mathrm{k} \text { ). }\end{array}$ \\
\hline 3 & $\begin{array}{l}\text { Text Citation and } \\
\text { Study Materials }\end{array}$ & $\begin{array}{l}\text { Full textbook citation (if applicable) and any additional } \\
\text { reference materials issued to the student. }\end{array}$ \\
\hline 4 & $\begin{array}{l}\text { Homework } \\
\text { Assignments and } \\
\text { Samples of } \\
\text { Student Work }\end{array}$ & Self explanatory. \\
\hline 5 & $\begin{array}{l}\text { Projects and } \\
\text { Samples of } \\
\text { Student Work }\end{array}$ & Self explanatory. \\
\hline 6 & $\begin{array}{l}\text { Laboratory } \\
\text { Experiments and } \\
\text { Samples of } \\
\text { Student Work }\end{array}$ & Self explanatory. \\
\hline 7 & $\begin{array}{l}\text { Exams and } \\
\text { Samples of } \\
\text { Student Work }\end{array}$ & Self explanatory. \\
\hline 8 & $\begin{array}{l}\text { Course-level } \\
\text { Assessments that } \\
\text { Contribute to } \\
\text { Program-level } \\
\text { Assessment Plan } \\
\text { - Performance } \\
\text { Criteria and Most } \\
\text { Recent Data }\end{array}$ & $\begin{array}{l}\text { Behind this tab is an end of semester summary sheet } \\
\text { organized by course objective (see sample form, Figure 1). } \\
\text { For each course objective, an assessment instrument is } \\
\text { named (chosen by the faculty member of record for the } \\
\text { course) and a standard for acceptable achievement on that } \\
\text { instrument is listed. The current semester's results are noted } \\
\text { alongside the standard (set by the faculty of record for the } \\
\text { course). Also noted is the average of students' self- } \\
\text { assessment responses ( } 5 \text { point scale) to the question of } \\
\text { whether or not they achieved that course objective. Finally, } \\
\text { continuous improvement actions planned based on the } \\
\text { current semester's learning outcome results are listed, again } \\
\text { by course objective. A log of these continuous improvement } \\
\text { action plans, results, AND any additional actions that did not } \\
\text { fit the by-objective organization scheme appear behind } \\
\text { Tab10. }\end{array}$ \\
\hline 9 & $\begin{array}{l}\text { Course-level } \\
\text { Assessments that } \\
\text { Contribute to } \\
\text { Program-level } \\
\text { Assessment Plan } \\
\text { - Historical Data }\end{array}$ & $\begin{array}{l}\text { This tab is intended to contain graphs depicting semester to } \\
\text { semester results from the summary sheets initially filed } \\
\text { behind Tab8. Because this binder arrangement was } \\
\text { established during Fall semester 2004, it is likely that this tab } \\
\text { will be incomplete for most binders. One semester's worth } \\
\text { of historical data is expected (namely Fall 2004), but not } \\
\text { enough data exists to justify graph creation. }\end{array}$ \\
\hline $\mathbf{1 0}$ & $\begin{array}{l}\text { Continuous } \\
\text { Improvement }\end{array}$ & $\begin{array}{l}\text { This tab is to be used for a running log of continuous } \\
\text { improvement actions planned and completed. }\end{array}$ \\
\hline
\end{tabular}


Binder tabbed sections 8, 9, and 10 are particularly important to this assessment process. This is where the Summary of Student/Course Outcomes, shown in Figure 1, is presented along with course improvement actions. According to the assessment plan, all faculty members will conduct course assessments at the completion of each semester for the courses they taught. Data gathered during this process is used to make adjustments and improve the student learning experience. Examples of assessment methods used are: assignments, labs, exams, quizzes, and performance projects.

This method of collecting data related to specific course objectives or learning outcomes is used as the metric for how well students are performing related to POs. The acceptable achievement level selected for this performance is that $70 \%$ of the students perform at a level of $70 \%$ or better for each of the course competencies. This process remains in place today for the present assessment and evaluation plan. The course improvements are summarized each year in a Summary of Program Improvements document.

Figure 1- Summary of Student/Course Outcomes

\begin{tabular}{|c|c|c|c|c|c|c|}
\hline \multirow{2}{*}{$\begin{array}{c}\text { Course } \\
\text { Objectives } \\
\text { (As found on } \\
\text { course } \\
\text { syllabus) }\end{array}$} & \multirow{2}{*}{$\begin{array}{c}\text { Relates to } \\
\text { Program } \\
\text { Outcome }(s) \\
\\
(A B E T \\
\text { Specific } a-k)\end{array}$} & \multirow{2}{*}{$\begin{array}{c}\text { Course } \\
\text { Assessment } \\
\text { Method \& } \\
\text { Metrics } \\
\\
\text { (How do you } \\
\text { measure } \\
\text { accomplishme } \\
\text { nt of course } \\
\text { objectives?) }\end{array}$} & \multicolumn{3}{|c|}{ Student Course Learning Outcomes } & \multirow{2}{*}{\begin{tabular}{|l|}
\multicolumn{1}{c}{ Course Improvement } \\
Actions
\end{tabular}} \\
\hline & & & Standard & Results & $\begin{array}{c}\text { Acceptab } \\
\mathbf{Y} / \mathbf{N}\end{array}$ & \\
\hline $\begin{array}{l}\text { Provide the } \\
\text { engineering } \\
\text { student with } \\
\text { a broad } \\
\text { realistic } \\
\text { understandin } \\
\text { g of the } \\
\text { design } \\
\text { process. }\end{array}$ & $\begin{array}{l}2 \mathrm{~A}, \text { degree } 2 \\
2 \mathrm{~B}, \text { degree } 1 \\
2 \mathrm{C} \text {, degree } 2 \\
2 \mathrm{D} \text {, degree } 3 \\
2 \mathrm{E} \text {, degree } 3 \\
2 \mathrm{~F} \text {, degree } 3 \\
2 \mathrm{G} \text {, degree } 3 \\
2 \mathrm{H} \text {, degree } 1 \\
2 \mathrm{I} \text {, degree } 2 \\
2 \mathrm{~J}, \text { degree } 2 \\
2 \mathrm{~K} \text {, degree } 1 \\
8 \mathrm{~A}, \text { degree } 2 \\
8 \mathrm{~B} \text {, degree } 1\end{array}$ & $\begin{array}{l}\text { Written exams, } \\
\text { classroom } \\
\text { activities, } \\
\text { homework } \\
\text { assignments, } \\
\text { lab team } \\
\text { projects related } \\
\text { to } 28 \text { week } \\
\text { senior project } \\
\text { matrix, and } \\
\text { team oral } \\
\text { project } \\
\text { presentation. }\end{array}$ & $\begin{array}{l}70 \% \text { of } \\
\text { students } \\
\text { will score } \\
70 \% \text { or } \\
\text { better on } \\
\text { exams, } \\
\text { assignments } \\
\text {, labs, and } \\
\text { presentation } \\
\text { s. }\end{array}$ & $\begin{array}{l}93 \%>70 \% \text { on } \\
\text { written exams } \\
100 \%>70 \% \text { on } \\
\text { assignments } \\
100 \%>70 \% \text { on } \\
\text { lab projects } \\
100 \%>70 \% \text { on } \\
\text { project } \\
\text { presentation }\end{array}$ & $\mathrm{Y}$ & $\begin{array}{l}\text { Limit group size to three } \\
\text { students, Advise a project } \\
\text { group while teaching } \\
\text { course, chapter quizzes } \\
\text { through WebCT, Develop } \\
\text { GD\&T module for } \\
\text { WebCT, Strictly enforce } \\
\text { lab due dates. }\end{array}$ \\
\hline
\end{tabular}

Finally, in the Self Study Report an Assessment Plan, shown in Figure 2, was provided listing each PEO and PO with the corresponding assessment criteria, results, and use of results. At this time the assessment plan was just underway and no significant data was presented to show that the data collected was being used for continuous improvement. 
Figure 2 - Self Study Report Assessment Plan

Criteria 3. Assessment \& Evaluation - Program Outcomes

Recipients of the Engineering Technology Option in Mechanical Engineering Technology BS degree from Michigan Tech demonstrate:

\begin{tabular}{|l|l|l|l|}
\hline $\begin{array}{l}\text { INTENDED } \\
\text { OUTCOME }\end{array}$ & $\begin{array}{l}\text { ASSESSMENT } \\
\text { CRITERIA }\end{array}$ & RESULTS & USE of RESULTS \\
$\begin{array}{l}\text { (a) an appropriate } \\
\text { mastery of the } \\
\text { knowledge, } \\
\text { techniques, skills } \\
\begin{array}{l}\text { and modern tools } \\
\text { of their disciplines }\end{array}\end{array}$ & $\begin{array}{l}\text { a1. } 75 \% \text { of the } \\
\text { students will } \\
\text { demonstrate mastery } \\
\text { of course objectives } \\
\text { relating to this } \\
\text { program outcome } \\
\text { when measured at } \\
\text { the course level. }\end{array}$ & $\begin{array}{l}\text { a1. } \\
\text { Gample courses }=90.91 \%\end{array}$ & $\begin{array}{l}\text { a1.See course binders } \\
\text { for continuous } \\
\text { improvement actions }\end{array}$ \\
\hline
\end{tabular}

\section{Reaccreditation Report}

In the Reaccreditation report the revised PEOs were presented, changing from the previous (4) stated PEOs to a list of (6) PEOs related to the qualities, that 3-5 years after graduation from the MET program, our graduates will be capable of achieving. The a-k criteria were listed as the POs, the Updated List of PEOs were linked with the a-k criteria, and outcome assessment methods/metrics were provided for each PEO. An example of one of the updated PEOs is shown in Figure 3.

\section{Figure 3 - Updated List of Program Educational Objectives}

\section{Mechanical Engineering Technology: Program Objective \#3 Mechanical engineering technology graduates will work in cross-functional teams providing expert knowledge as technologists.}

\begin{tabular}{|c|c|c|c|}
\hline \multirow{2}{*}{$\begin{array}{c}\text { Strategies and } \\
\text { Actions }\end{array}$} & \multirow{2}{*}{$\begin{array}{l}\text { Outcomes: } \\
\text { Criterion 3. a-k \& Criterion } 8 \mathrm{a}, \mathrm{b}, \mathrm{c} \\
\text { Graduates will have: }\end{array}$} & \multicolumn{2}{|c|}{$\begin{array}{l}\text { Outcomes Assessment } \\
\text { Methods/Metrics }\end{array}$} \\
\hline & & Direct & Indirect \\
\hline $\begin{array}{l}\text { Evaluate the } \\
\text { senior project } \\
\text { design and build } \\
\text { projects for } \\
\text { application of } \\
\text { skills obtained in } \\
\text { earlier core } \\
\text { engineering class } \\
\text { work and their } \\
\text { ability to perform } \\
\text { as a team. } \\
\text { Utilize the yearly } \\
\text { binder process to } \\
\text { assure that } \\
\text { adequate focus is }\end{array}$ & $\begin{array}{l}\text { a. An appropriate mastery of the } \\
\text { knowledge, techniques, skills and } \\
\text { modern tools of the discipline } \\
\text { b. An ability to apply current } \\
\text { knowledge and adapt emerging } \\
\text { applications of mathematics, } \\
\text { science, engineering and } \\
\text { technology } \\
\text { c. An ability to conduct, analyze } \\
\text { and interpret experiments and } \\
\text { apply experimental results to } \\
\text { improve processes } \\
\text { d. An ability to apply creativity in } \\
\text { the design of systems, components } \\
\text { or processes appropriate to the }\end{array}$ & $\begin{array}{ll}\text { - } & \text { Peer review by } \\
\text { industrial } \\
\text { advisory board } \\
\text { - Peer review by } \\
\text { faculty } \\
\text { - Outcomes of } \\
\text { senior design } \\
\text { completion } \\
\text { - Peer evaluation } \\
\text { rubric utilized in } \\
\text { senior project } \\
\text { Peer evaluation } \\
\text { rubrics utilized in } \\
\text { MET courses. }\end{array}$ & $\begin{array}{ll}- & \text { Exit survey } \\
\text { - } & \text { Alumni } \\
& \text { Survey }\end{array}$ \\
\hline
\end{tabular}




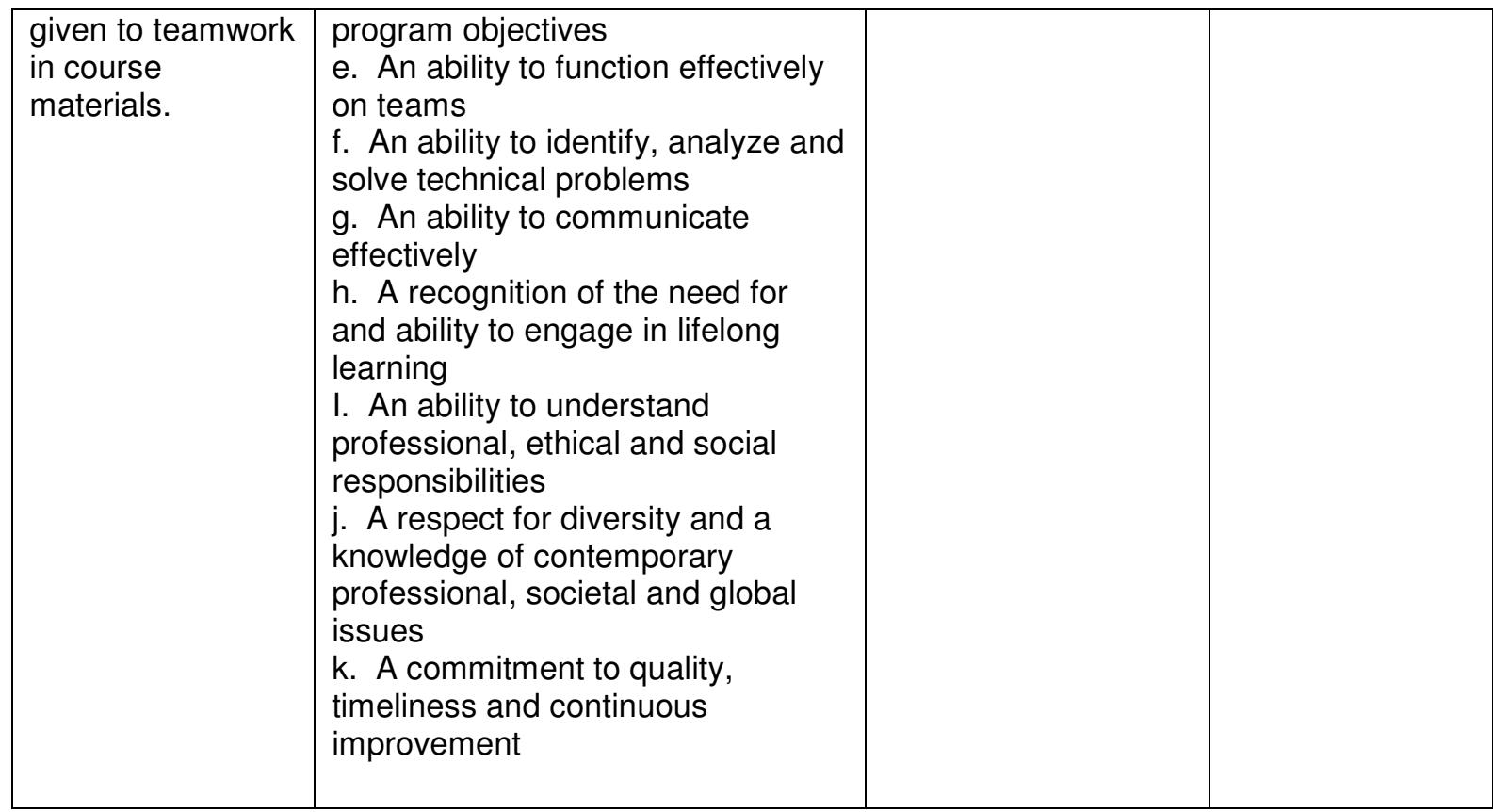

The part of this documentation that perceivably caused the ABET response of a continued Weakness is that several PEOs were listed with PO's aligned which had no bearing on that particular PEO. Also, the measures that were listed were not consistent with the separation between measuring outcomes from the current students verses the evaluation of student characteristics 3-5 years after graduation. The example shown in Figure 3 shows one of the PEOs that was commented on by the ABET reviewers where all a-k criteria were shown as aligned, but clearly they do not all relate to the PEO describing the capability to work in teams. Also, some of the methods and metrics used for assessment were not measuring the capabilities of students 3-5 years after graduation. For example, the evaluation of senior design projects and rubrics in MET courses are measurements of POs, but are not appropriate for measuring the PEO listed.

It is important to note here that training provided by ABET through the online webinars, such as "Defining Program Outcomes" by Gloria Rogers", and periodic "Assessment Tips With Gloria Rogers" published on the ABET website ${ }^{2,3}$ were very helpful in making this distinction between PEOs and POs more evident to the MET Program Assessment Team.

\section{MET Program Spring 2008 Assessment Report}

In this assessment report the main focus was to illustrate the distinction between PEOs and POs and the assessment measure and metrics associated with each objective. Also, to illustrate the program improvements that had been implemented over the past year in response to the data gathered. The first table presented in the report, shown in Figure 4, is a matrix of the relationship between the PEOs and the POs, which illustrates that not every PEO is related to each PO. 


\section{Figure 4 - PEO/PO Matrix}

\begin{tabular}{|l|l|l|l|l|l|l|l|}
\hline \multicolumn{7}{|c|}{ Program Educational } \\
\hline Objectives - PEOs \\
\hline PO1 & $\begin{array}{l}\text { An appropriate mastery of the knowledge, techniques, skills and } \\
\text { modern tools of the discipline (ABET 2.a ) }\end{array}$ & & & & & \\
\hline $\mathbf{P O 2}$ & $\begin{array}{l}\text { An ability to apply current knowledge and adapt emerging } \\
\text { applications of mathematics, science, engineering and technology } \\
\text { (ABET 2.b ) }\end{array}$ & X & & & & \\
\hline $\mathbf{3}$ & $\begin{array}{l}\text { An ability to conduct, analyze and interpret experiments and apply } \\
\text { experimental results to improve processes (ABET 2.c) }\end{array}$ & X & & & & & \\
\hline $\mathbf{4}$ & $\begin{array}{l}\text { An ability to apply creativity in the design of systems, components } \\
\text { or processes appropriate to the program objectives (ABET 2.d ) }\end{array}$ & X & & & & & \\
\hline $\mathbf{5}$ & An ability to function effectively on teams (ABET 2.e ) & X & X & X & X & & \\
\hline $\mathbf{6}$ & $\begin{array}{l}\text { An ability to identify, analyze and solve technical problems (ABET } \\
\text { 2.f })\end{array}$ & X & X & X & & & \\
\hline
\end{tabular}

Next, a table was provided as a summary of the assessment tools, shown in Figure 5. A brief description of each tool was provided for further clarification. This makes it very clear that the distinction between the PEOs and the POs is that the PEOs are measured using indirect measures such as placement data and surveys of employees and alumni.

Figure 5 - Assessment Tools

\begin{tabular}{|c|c|c|c|}
\hline & Assessment Tool & $\begin{array}{c}\text { Responsible for } \\
\text { Data Collection/Analysis }\end{array}$ & Frequency \\
\hline \multirow{6}{*}{ రి } & Summary of Course Outcomes & Faculty & Semester \\
\hline & Student Rating of Instruction & $\begin{array}{c}\text { Center for Teaching, Learning } \\
\text { \& Faculty Development }\end{array}$ & $\begin{array}{c}\text { Semester } \\
\text { (All courses) }\end{array}$ \\
\hline & Senior Exit Survey & SOT Staff & Semester \\
\hline & Senior Project Evaluation & Faculty & Annually \\
\hline & SME certification Test & SME & Semester \\
\hline & Benchmarking & Faculty & Triennially \\
\hline \multirow{4}{*}{$\begin{array}{l}0 \\
\stackrel{1}{2}\end{array}$} & Job Placement & University Career Center & Semester \\
\hline & Alumni Survey & University Career Center & Triennially \\
\hline & Employer Survey & University Career Center & Triennially \\
\hline & Input from Industrial Advisory Board & Faculty & Annually \\
\hline
\end{tabular}

Most of the categories of data collection listed here are common to most assessment plans, but the methodologies may be somewhat innovative. One of these innovative methods used here by the Assessment Team was to create the surveys on an internet website: www.PollDaddy.com. This low cost subscription internet service allows the data to be collected digitally and reported in a consistent manner without the costs of duplication of several pages and cost of mailings. Email was used to contact employers with the help of the University Career Services and Alumni Relations to contact former 
students. Notice that these measures are not collected every year, because the collection of this data still takes significant amount of time to analyze.

The Student Rating of Instruction (SRI) used here is an early student feedback mechanism prior to student graduation. This is a 20 question instrument with each question rated on a 1-5 scale with 1 as "Strongly Disagree" and 5 as "Strongly Agree". Items 1-18 are intended to be formative in nature and are based on contemporary "best practice" models derived from higher education research and reflection. Items 19 and 20 are intended to elicit responses from students as to their overall assessment of instruction. Student input is used to improve teaching and learning techniques used in the classroom as well as to improve curriculum and laboratory facilities. Typically, instructors will utilize the SRI instrument 10 optional questions to have students rate the overall achievement of the course objectives, which are correlated to the POs in the binder process. The 10 optional questions on the SRI are not to be used for merit or tenure/promotion decisions, and are very helpful for the continuous improvement action plan.

Next, an Assessment Analysis of POs, shown in Figure 6, was used to indicate the a-k criteria being used to evaluate graduates, the methods used to evaluate the criteria, the metrics, and the Results/Actions implemented to address the data. The Summary of Course Outcomes, (shown in Figure 1), is the method of measurement used in this analysis. The metric used for this assessment is that $70 \%$ of the students perform at a level of $70 \%$ or better for each of the course competencies mapped to the a-k criteria. The $70 \%$ level of achievement correlates to the $2.0 \mathrm{GPA}$ in their major required courses required for graduation.

\section{Figure 6 - Assessment Analysis of POs}

\begin{tabular}{|c|c|c|c|}
\hline \multirow{2}{*}{$\begin{array}{l}\text { Program graduates will be } \\
\text { capable of: }\end{array}$} & \multicolumn{3}{|c|}{ Program Outcome Assessment } \\
\hline & Methods & Metrics & Results/Actions \\
\hline $\begin{array}{l}\text { a. An appropriate } \\
\text { mastery of the } \\
\text { knowledge, } \\
\text { techniques, skills and } \\
\text { modern tools of the } \\
\text { discipline } \\
\text { b. An ability to apply } \\
\text { current knowledge } \\
\text { and adapt emerging } \\
\text { applications of } \\
\text { mathematics, science, } \\
\text { engineering and } \\
\text { technology } \\
\text { c. An ability to conduct, } \\
\text { analyze and interpret } \\
\text { experiments and } \\
\text { apply experimental }\end{array}$ & $\begin{array}{l}\text { - Summary of } \\
\text { Course } \\
\text { Outcomes } \\
\text { - Analysis } \\
\text { includes input } \\
\text { from both } \\
\text { Program } \\
\text { Outcome and } \\
\text { Program } \\
\text { Educational } \\
\text { Objective } \\
\text { assessment } \\
\text { methods. } \\
\text { Targets all } \\
\text { criterion } 2 \text { a- } \\
\text { k \& criterion } \\
8 \text { a-c }\end{array}$ & $\begin{array}{l}70 \% \text { of } \\
\text { students will } \\
\text { score } 70 \% \text { or } \\
\text { better on the } \\
\text { assessment } \\
\text { metric for each } \\
\text { of the course } \\
\text { objectives that } \\
\text { are correlated } \\
\text { to the program } \\
\text { outcomes. }\end{array}$ & 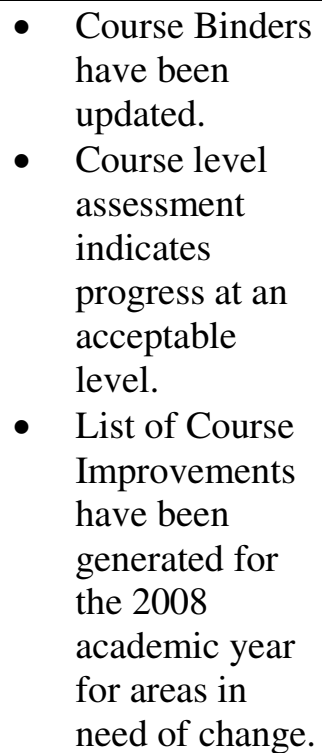 \\
\hline
\end{tabular}




\begin{tabular}{|c|c|c|c|}
\hline $\begin{array}{l}\text { results to improve } \\
\text { processes }\end{array}$ & $\begin{array}{ll}\text { - } & \text { Student } \\
\text { Rating of } \\
\text { Instruction } \\
\text { - } \\
\text { Targets all } \\
\text { criterion } 2 \text { a- } \\
\text { k \& criterion } \\
8 \text { a-c }\end{array}$ & $\begin{array}{ll}- & \text { Rating of } \\
\text { Instruction } \\
\text { above a } 3.5 \\
\text { average for Q } \\
\text { 1-18, Q } 19 \& \text { Q } \\
\text { 20. }\end{array}$ & 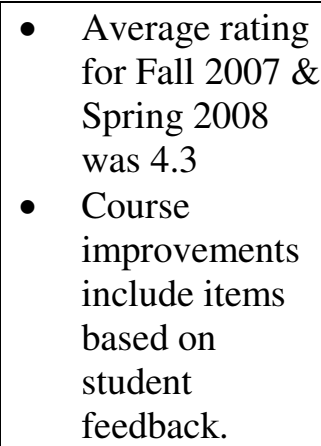 \\
\hline
\end{tabular}

Also, the Assessment Analysis of PEOs, shown in Figure 7, was used to indicate the a-k criteria aligned with this PEO, the methods used to evaluate the criteria, the metrics, and the strategies, progress and results implemented to address that data. At the time of this report not all the survey data had been collected, but the plan was communicated for the collection of the data.

\section{Figure 7 - Assessment Analysis of PEOs}

Program Educational Objective \#1: Mechanical engineering technology graduates will utilize their technical knowledge to collaborate in the improvement and creation of products and technologies that are viable and sustainable.

\begin{tabular}{|c|c|c|c|}
\hline \multirow{2}{*}{$\begin{array}{l}\text { During the first } 3-5 \text { years } \\
\text { after graduation our } \\
\text { graduates will demonstrate: }\end{array}$} & \multirow{2}{*}{$\begin{array}{l}\text { Strategies, Progress, } \\
\text { and Results }\end{array}$} & \multicolumn{2}{|c|}{ Educational Objective Assessment } \\
\hline & & Methods & Metrics \\
\hline $\begin{array}{l}\text { a. An appropriate } \\
\text { mastery of the } \\
\text { knowledge, } \\
\text { techniques, skills } \\
\text { and modern tools of } \\
\text { the discipline } \\
\text { b. An ability to apply } \\
\text { current knowledge } \\
\text { and adapt emerging } \\
\text { applications of } \\
\text { mathematics, } \\
\text { science, } \\
\text { engineering and } \\
\text { technology } \\
\text { c. An ability to } \\
\text { conduct, analyze } \\
\text { and interpret } \\
\text { experiments and } \\
\text { apply experimental } \\
\text { results to improve } \\
\text { processes }\end{array}$ & $\begin{array}{l}\text { Strategies: } \\
\text { Offer courses in the } \\
\text { MET program area that } \\
\text { require excellence in } \\
\text { technical knowledge } \\
\text { and application. } \\
\text { Continuous } \\
\text { improvement of } \\
\text { program curriculum. } \\
\text { Progress: } \\
\text { Alumni and } \\
\text { Employer Survey } \\
\text { conducted in 2003, and } \\
\text { Advisory Board Input } \\
\text { Fall 2008. Alumni and } \\
\text { Employee survey } \\
\text { conducted May 2008. } \\
\text { Results: } \\
\text { IAB action items } \\
\text { updated for 2008, } \\
\text { Recent Alumni and } \\
\text { Employer survey have } \\
\text { no results to date. }\end{array}$ & $\begin{array}{ll}\text { - } & \text { Alumni } \\
\text { Survey } \\
\text { - Employer/ } \\
\text { Recruiter } \\
\text { Survey } \\
\text { - Advisory } \\
\text { Board } \\
\text { Input }\end{array}$ & $\begin{array}{l}70 \% \text { of survey } \\
\text { respondents rate } \\
\text { this objective at } \\
\text { a level above } \\
\text { average } \\
\text { performance. } \\
\text { - Advisory board } \\
\text { members } \\
\text { unanimously } \\
\text { support the } \\
\text { need for these } \\
\text { qualities in } \\
\text { graduates. }\end{array}$ \\
\hline
\end{tabular}




\section{PO \& PEO Assessment Results}

Results of the assessment measures, (described earlier as Assessment Tools in Figure 5), were presented in appendix format in the Spring 2008 Assessment Report. The results for the POs included data collected during 2007-08, and the PEOs for the past two years and most recent Alumni and Employer survey data analyzed, which was from 2003.

Additional data supplied to ABET in the Spring 2008 Assessment Report in appendix format were the following: List of Continuous Improvement Actions; MTU Student Rating of Instruction Instrument; Course Competency Mapping Matrix; and the Alumni and Employer Surveys. These documents along with assessment data shown in tabular format illustrated evidence of the implementation of the assessment plan over the past two to three years.

\section{Discussion}

Assessment and Evaluation, or Continuous Improvement in ABET 2008-09 terminology, is not a last minute end of the semester task as anyone involved in the process knows very well. The tools presented here are probably not a surprise to the reader, but using the tools in the correct manner is what is important to understand. From experience in going through the process of having a system where all the tools were in place, but were not being used in the correct manner gave the understanding of how to measure specific outcomes related to Program Outcomes, POs of current students, and the very different measures of Program Educational Objectives, PEOs relating to qualities of graduates 3-5 years after leaving the program.

Another important lesson learned is to communicate the assessment plan thoroughly with all faculty members involved in gathering and analyzing the assessment measures. Especially, close attention is necessary to control the quality of course level assessment of POs. Constant review of the mapping matrix of POs and course objectives is required as course material is updated and changed.

By far, the more difficult measures are the PEOs in respect to the measurement tools chosen in this assessment plan. Even with the automated internet survey tool used there is no way of predicting what type of a response rate to expect from employers and alumni. Industrial advisory board and career placement data are a more reliable source of feedback, but also have shortcomings. The advisory board members respective companies are representative of a small percentage of the total number of companies that graduates are employed.

\section{Conclusions}

Be clear in the definition of PEOs and POs, how they are aligned and what tools are used to measure each. Follow the assessment plan and use of tools with documentation of the data illustrated in tabular format to document progress. Also, the use of internet survey 
tools to collect data rather than the expensive and time consuming paper format surveys can be very advantageous.

The Assessment tools used to measure POs need to be unobtrusive enough that it does not disrupt the normal educational process, and not be a burden to the instructor of record. Creating a matrix of course objectives related to POs, and having a method in place to evaluate that course objective does not add an extra level of assessment just to satisfy the accreditation purpose. Then, the additional information necessary is the evaluation of the areas where students are not achieving to the level set as the metric and reflection on how to correct that in the future.

\section{Recommendations and Plans for the Future}

Incentives for students to take part in the Senior Exit Survey can be used to increase the response rate. For instance, the student can be given a small token of recognition for graduating from the program, a plaque or t-shirt with the program logo, if they submit confirmation that they have completed the online survey. Also, the exit exam may be an optional part of the curriculum, but if it is incorporated into a class and made mandatory it can increase the amount of data collection. If an outside exam through a society like SME or NAIT is used, the grading and analysis of results is provided by that service, which makes the data collection easier.

During the next several years leading up to the next accreditation report an additional piece of data to supplement the tools proposed is to choose some of the more difficult to measure criteria, and use rubrics to rate observations of students throughout the semester. For instance, these rubrics can be used for criteria like "Teamwork" or "Respect for Diversity" which are difficult to measure in a quiz, test, homework assignment, or even in a group project. The rubrics may or may not be used in the course grading, but at the end of the semester each instructor will tally the scores and the data will be displayed in a table compared to a metric for that criteria.

A caveat here is that these measurements of affective type criteria be measured on a cyclical basis so as to not overwhelm the instructor with several assessment criteria in one semester.

\section{Bibliography}

1. Rogers, G., Defining Program Outcomes, 2008 webinar CD, ABET Inc: 2008.

2. Rogers, G., The Language of Assessment: Humpty Dumpty Had a Great Fall. Assessment Tips With Gloria Rogers, Communications Link is a publication of ABET Inc; retrieved from www.abet.org on March 2008.

3. Rogers, G., Making a List and Checking It Twice. Assessment Tips With Gloria Rogers, Communications Link is a publication of ABET Inc; retrieved from www.abet.org on April 2008. 